Platskamp, specialnummer av

Arkiv. Tidskrift för sambällsanalys, nr 9 (2018)

\title{
Platskamp: inledande reflektioner
}

\section{Magnus Dahlstedt, Lisa Kings \& Nazem Tahvilzadeh}

SAMMANDRAG: Det här specialnumret är ett temanummer om hur kampen om förorten förs i vår samtid. Genom att uppmärksamma förorten som en politisk företeelse, skapad i spänningsfältet mellan reproduktion och motstånd, försöker författarna fånga den komplexa dynamik mellan olika intressen som präglar den urbana periferin. Med texter av Magnus Dahlstedt, Christophe Foultier, James Frempong, Lisa Kings, René León Rosales, Vanja Lozic, Nazem Tahvilzadeh och Aleksandra Ålund. Bidragens skilda perspektiv på förorten som skådeplats för politisk kamp och de "platskamper" som utspelar sig där öppnar upp för spännande samtal om detta ständigt återkommande tema: förorten, levd som föreställd.

NYCKELORD: förorten; politik; platskamp; kritisk urbanteori; postkolonial teori.

PUBLICERINGSHISTORIK: Originalpublicering.

MAGNUS DAHLSTEDT är professor i socialt arbete vid Linköpings universitet.

E-POSTADRESS: magnus.dahlstedt@liu.se

LISA KINGS är lektor i socialt arbete vid Södertörns högskola.

E-POSTADRESs: lisa.kings@sh.se

NAZEM TAHVilzadeH är forskare vid Kungliga Tekniska högskolan.

E-POSTADRESS: nazem.tahvilzadeh@abe.kth.se

FÖRSLAG PÅ KÄLLANGIVELSE:

Dahlstedt, Magnus, Lisa Kings \& Nazem Tahvilzadeh (20I8) "Platskamp: inledande reflektioner", i Platskamp, specialnummer av Arkiv. Tidskrift för samhällsanalys, nr 9, s. $7-25$.

DoI: https://doi.org/10.13068/2000-6217.9.F

(C) Författarna/Arkiv förlag \& tidskrift 2018 (publicerad 28 maj 20ı8)

Artikeln distribueras enligt en upphovsrättslicens från Creative Commons:

Erkännande-Ickekommersiell-IngaBearbetningar 3.0 Unported, som medger fri ickekommersiell användning och spridning i oförändrat skick så länge källan anges. 
Arkiv. Tidskrift för samhällsanalys är en sakkunniggranskad vetenskaplig tidskrift för samhällsvetenskap och historia. Samtliga artiklar publiceras fritt tillgängliga på:

$$
\text { www.tidskriftenarkiv.se }
$$

Beständig länk, DOI: https://doi.org/IO.I3068/2000-62I7

Den här artikeln finns tillgänglig i följande format:

PDF: via beständig länk, DoI: https://doi.org/Io.13068/2000-6217.9.F

TRYCK: ingår i bokutgåva av numret, ISBN: 978 9I 79243159

Grafisk utformning och sidnumrering är identisk i pdf och tryck.

Samtliga artiklar i nr 9 (2018), Platskamp, nås via beständig länk, DOI: https://doi.org/I0.I3068/2000-6217.9

Redaktion för nUmret: Magnus Dahlstedt, Lisa Kings \& Nazem Tahvilzadeh

Arkiv. Tidskrift för samhällsanalys

ISSN: 2000-62I7 (för elektronisk resurs)

ISSN: 2000-6225 (för tryckta nummer)

ges ut av

Stiftelsen Arkiv för främjande och spridning av samhällsvetenskaplig och historisk forskning

\author{
genom \\ Arkiv förlag \& tidskrift \\ Box 1559 \\ SE-22I OI Lund \\ BESÖK: L Gråbrödersg 3 c, ipg \\ TEL: 046-I3 3920
}

ARKIV FÖRLAG: arkiv@arkiv.nu·www.arkiv.nu

TIDSKRIFTEN ARKIV: red@tidskriftenarkiv.se.www.tidskriftenarkiv.se

ANSVARIg UTGIVARE \& CHEFREDAKTÖR: Sven Hort

AdMinistrativ Redaktör: David Lindberg

Redaktörer: Paavo Bergman, Per Dannefjord, Lisa Kings,

Zhanna Kravchenko, Anna-Maria Sarstrand Marekovic 


\title{
Platskamp: inledande reflektioner
}

\author{
MAGNUS DAHLSTEDT, LISA KINGS \\ $\&$ NAZEM TAHVILZADEH
}

(Stor)staden är förvisso ett syndens näste, ett Babylon [...] men så länge synden inte hotar stadens reproduktion, dvs. reproduktionen av rikedomar i de redan rikas händer och av själva föreställningen av staden såsom ideologisk enhet och fästpunkt för löften om njutning, kommer synden att få fortgå. De verkliga hoten kommer i stället från dem som angriper stadens grundelement, från dem som stör den imaginära kraft som stadens namn härbegerar, från dem som ställer obehagliga frågor om stadens egentliga grundvalar [...] (Azar 2006, s. 139f.)

Detta specialnummer av tidskriften Arkiv behandlar ett av de mest angelägna samtalsämnena inom samtida politisk debatt - förorten, som i debatten antagit många olika skepnader: Förorten som plats och som ickeplats. Förorten som orsaken till sociala problem - och som lösningen på desamma. Förorten som hot och som resurs. Förorten som ett kaosets och sammanhållningens rum. Förorten som realitet och som fantasi. Förorten som utanför eller som innanför. Förorten som säte för bakåtsträvande, fundamentalism och extremism och som inkubator för innovation, förnyelse och entreprenörskap. Förorten som föremål för politisk styrning och som knutpunkt för politiskt motstånd. Förorten som stigma, som tillskriven identitet, och som levd erfarenhet.

Varför över huvud taget ge oss in i denna debatt, som har förts under så lång tid? En debatt som redan erbjudit så många inspel, förklaringar

Arbetet med detta specialnummer har finansierats av Formas (projektnummer 250-2013I547) och Vetenskapsrådet (projektnummer 72I-20I3-885). 
och diagnoser? Är inte allt som är möjligt att säga redan sagt? Vad är poängen med att återigen aktualisera frågan om just förorten, dess plats i samtiden och inför framtiden?

\section{Förorten som politik}

Vi menar att förorten är viktig att undersöka närmare därför att förorten inte är en och densamma. I den offentliga debatten är förorten allt och ingenting. Man skulle kunna säga att förorten inte finns. Den blir till. Förorten kan här närmast ses som ett slags symboliskt objekt. I den process där förorten blir till fungerar förorten som en container för skilda viljor, för krafter som önskar mobilisera olika värden. För olika ändamål. För den som önskar åstadkomma något - vad det nu än må vara - finns förorten alltid tillhanda för att förverkliga detta något - må det vara drömmar såväl som mardrömmar. För förortens invånare kan förorten fungera som en kuliss för identitetsskapande och kollektiv handling eller som något man drömmer om att lämna, medan den för myndigheter och intresseorganisationer kan fungera som motiv till intervention och uppvisande av handlingskraft i kampen om uppmärksamhet i en alltmer medialiserad politisk samtid. Vi menar att förorten i den allmänna debatten är ett symboliskt objekt som blir till genom ett dynamiskt och motsättningsfullt möte mellan olika krafter som sammanför en rad politiska intressen mot bakgrund av asymmetriska maktrelationer (jfr Azar 2006). Förorten är på så sätt politik.

Det förs en ständig kamp om förorten. En kamp som bland annat handlar om att fylla detta symboliska objekt med värden, att fastslå dess symtom, artikulera dess intressen och tillgodose dess behov. Denna kamp är en politisk kamp. Förorten är en skådeplats för politik lika mycket som ett resultat av politik. Det innebär att förorten är en viktig källa till kunskap, inte bara om förorten som sådan, utan om samhället som sådant, om maktrelationer och ojämlikhet, om reproduktion och motstånd. Det är därför viktigt att närmare undersöka förorten, inte bara som ett objekt, som en fysisk realitet, i vilket hänseende vi nu må tänka kring den, utan också som just en skådeplats för politisk kamp. Hur kan vi förstå dessa samtida "platskamper"? Vad har gjort dem möj- 
liga och vad möjliggör de i sin tur? Vad är dessa kamper ett uttryck för eller symtom på? Det är kring dessa frågor som detta temanummer uppehåller sig.

\section{Behovet av perspektivskifte}

Det finns mängder av undersökningar som ägnats åt att kartlägga och analysera tillståndet i landets förortsområden. Utifrån dessa undersökningar kan följande bokslut göras: Under de senaste decennierna har det skett en accelererande tudelning och polarisering av de svenska städerna, där de sociala, ekonomiska och politiska villkoren i stadens periferier gradvis har utarmats och klyftorna i den urbana geografin sammantaget har ökat (t.ex. Andersson m.fl. 2009; Socialstyrelsen 20I0; Aldén m.fl. 2015; Stigendal 2016). Detta paradoxalt nog trots ständigt återkommande försök att genom olika insatser bryta segregationen och motverka dess effekter (Andersson 2008; Urban 2018).

Undersökningar har pekat på att hushåll med utländsk bakgrund och med låga inkomster har begränsade möjligheter till annat boende och som en följd av detta koncentreras just dessa hushåll till vissa delar av städerna, inte sällan till förortsområden i städernas utkanter (Molina 1997; Magnusson Turner 2008). Med utförsäljningar av allmännyttan och omvandling av hyresrätter till bostadsrätter, inte minst i områden i städernas innerkärnor och närförorter, har - omvänt - allt fler resursstarka hushåll flyttat till områden som tidigare varit blandade (Lilja 20II).

Städerna faller därför bildligt talat isär och blir alltmer uppdelade. Resursstarka och resurssvaga grupper bor alltmer geografiskt isolerade från varandra, i olika delar av staden. I en kartläggning av segregationen i Stockholms stad genomförd av SCB 2014 dras exempelvis följande slutsats:

Mest anmärkningsvärd är den starka ökningen av den ekonomiska segregationen där fattiga (både enligt EU:s definition men även mätt som den fattigaste ıo:e percentilen) är mer isolerade i dag än tidigare och där stora delar av fattiga individers omgivning ... består av andra fattiga. Än mer isolerad är gruppen rika som lever mer åtskilt än tidigare och som i allt större utsträckning lever sina vardagsliv utan möte eller med få möten med fattiga individer. (SCB 20I4, s. 25.) 
Mönstret gäller dock inte bara Stockholm eller ens de tre största städerna, utan även medelstora och för den delen även mindre städer runt om i landet (Salonen 20II; Fell \& Guziana 20I6).

Det är i forskningen också väl belagt att det offentliga samtalet under flera decennier har dominerats av en överdriven, dramatiserad och huvudsakligen problemorienterad berättelse om förorten, som en avvikande och hotfull plats, fylld av konflikter, faror och risker (se t.ex. Ristilammi 1994; Dahlstedt 2005, 2016; Ericsson 2007). Förorten gestaltas här som ett geografiskt område beläget vid sidan av och åtskilt från det övriga svenska samhället. Den dominerande berättelsen om förorten bygger därmed på ett upprättande av gränser mellan ett innanför - det normala svenska samhället - och ett utanför - förortens "parallellsamhälle". Utifrån denna åtskillnad lokaliseras en rad konflikter och problem i samhället just till den urbana periferin - i form av "kulturkrockar" och skolmisslyckanden (Pripp 2002; Tedros 2008), men på senare tid framför allt med fokus på social oro, extremism, gängrivalitet, våld och ungdomskriminalitet (Dahlstedt 20I8).

Dessa undersökningar och kartläggningar har bidragit och bidrar fortsatt till viktig kunskap om förorten, segregationen och dess utmaningar i samtiden. Samtidigt tenderar dessa undersökningar och kartläggningar alltför ofta att negligera den avgörande fråga som vi vill adressera i detta temanummer - nämligen hur förs kampen om förorten? Var någonstans utspelas denna kamp? Vad gör den möjlig? I de fall där kampen om förorten undersökts i tidigare forskning så har uppmärksamhet mestadels riktats mot enskilda platser, arenor och aktörer. Därmed har den kunskap som denna forskning bidragit med inte i tillräckligt hög grad lyckats fånga de friktioner och den komplexa dynamik mellan olika arenor och olika nivåer som präglar kampen om förorten. Vi vill med detta specialnummer bidra till att fylla denna lucka. För att kunna förstå den avgörande frågan om hur kampen om förorten förs $\mathrm{i}$ vår samtid krävs ett analytiskt perspektiv som riktar ljuset mot förorten som en politisk företeelse, skapad i spänningsfältet mellan reproduktion och motstånd. 


\section{Förorten - en produkt av maktrelationer}

Vi närmar oss förorten som en produkt av samhällets maktrelationer. Det innebär att vi ser förorten som skapad av processer som utspelats i det förflutna likväl som de utspelas i vår samtid (jfr Massey 2005). För att förstå hur det har kommit sig att förorten blivit till den offentliga debattens mittpunkt krävs en närmare analys av statsapparatens funktioner och interventioner, och de sätt på vilka de bidrar till att återskapa såväl som förändra den sociala ordningen. För att göra detta hämtar vi inspiration från såväl den kritiska urbanteorin som den postkoloniala forskningstraditionen.

Historiskt har kapitalismens utbredning varit intimt förknippad med stadens tillväxt. Samtidigt tenderar den ojämlikt fördelade tillväxten att generera friktioner och sociala spänningar i staden. Det är just på denna grund som den moderna välfärdsstaten vilar, som ett medel för att hantera och om möjligt mildra effekterna av de friktioner och spänningar som följer i strävan efter tillväxt.

Uttryckt på ett annat sätt är det genom städerna som statens välfärdsambitioner distribueras och materialiseras (Cockburn 1977; Harvey 1989). Inom den kritiska urbanteorin har detta teoretiserats vidare i termer av att kollektiv konsumtion har blivit en central konfliktlinje utöver den mellan arbete och kapital (Castells 1977; jfr Harvey 1976). Med kollektiv konsumtion avses de varor och tjänster som produceras och konsumeras kollektivt som infrastruktur, kollektivtrafik, skolor, räddningstjänst och sjukvård. Den kollektiva konsumtionen är naturligtvis inte begränsad till städer, men det är just i städerna som det blir särskilt tydligt hur vissa platser i staden missgynnas och andra gynnas av ojämlikt fördelade förmåner. Social ojämlikhet och dess avspegling i vardagslivets domän utgör på så sätt en grund för konflikt och möjlig utgångspunkt för motstånd i staden (Castells 1983).

Stadens roll i mer samtida kritisk urbanteori ses i relation till en ny period av ekonomisk, politisk och social förändring. Utifrån de alltmer globala aspekterna av dagens förändringsprocesser som fordismens kris, en ny internationell arbetsdelning och de multinationella företagens frammarsch framhålls att staden har intagit en särskild nyckelposition 
(Brenner \& Theodore 2002). Förskjutningen uppåt, bortom nationalstatens gränser och behovet att hävda sig i den globala konkurrensen har parallellt också inneburit en förskjutning nedåt mot staden. Det är på denna nivå, i staden, som vi finner försöken att finna strategier för att främja ekonomisk utveckling genom att försöka omvandla staden till en vinstmaskin, exempelvis genom offentliga satsningar för att höja fastighetsvärden, främja kommersiella aktiviteter, märkesprofilering, spektakulära evenemang och exklusiv stadsutveckling med arkitektoniska paradprojekt (Holgersen 20I7). I idén om den så kallade entreprenörsstaden ses staden som ett nytt politikskapande rum, med fokus på ekonomiska värden och regional konkurrens som uppmuntras genom en uppsjö av statliga påbud (Franzén m.fl. 20I6). Det samtida politiska fokuset på entreprenörskap och konkurrens kan förstås som en förskjutning från att staden under industrialismen sågs som en underkategori till nationen, och då med den främsta funktionen att stabilisera kapitalismen, till att stadens roll under postindustrialismen alltmer kommit att bli att främja den kapitalistiska utbredningen (Harvey 1989).

Det är med andra ord inte staden som helhet som är av betydelse för dess roll i den globala ekonomin. På stadens skuggsida finner vi områden som för denna funktion är obetydliga eller i vissa fall dysfunktionella. Därmed är det också i staden som vi finner försöken att hantera motsättningar och spänningar i syfte att stabilisera samtida omvandlingsprocesser med hjälp av kompletterande, repressiva eller skyddande strategier. Staden, och olika platser inom staden, kan i dag mer eller mindre ses som

[...] alltmer viktiga geografiska mål och institutionella laboratorier för en variation av nyliberala politiska experiment, från marknadsföring av platser, företags- och självhjälpszoner, lokala skatteavdrag, stadsutvecklingsbolag, offentliga-privata partnerskap, och nya former av lokal propaganda, till politik som förespråkar motprestationer i motsats till ett universellt socialt skyddsnät, fastighetsutvecklingssystem, projekt för att initiera nya företag, nya strategier för social kontroll, polisbevakning och övervakning, och en mängd andra institutionella modifikationer av den lokala och regionala statsapparaturen. (Brenner \& Theodore 2002, s. 2I, vår översättning.)

Metaforiken om närande och tärande är symtomatisk för denna tankelogik, som utgör grunden för nya gränsdragningar där det i Sverige är för- 
orten som görs till en olägenhet för staden som helhet. Utifrån detta har ojämlikhetens rumsliga gränsdragningar till viss del ritats om. Det gör det möjligt att diskutera om inte Immanuel Wallersteins (2007) tankefigur om centrum-(semiperiferi)-periferi, i sin klassiska världssystemteori, skulle kunna uppdateras. Vid sidan av distinktioner mellan syd och nord, eller öst och väst, skär de nya gränsdragningarna genom såväl nationer och kanske än tydligare genom städer.

\section{Den koloniala bumerangen}

Förorten fyller därför en liknande funktion i politiken som de avlägsna kolonierna gjorde för de europeiska kolonialmakterna. Vid sidan av den kritiska urbanteorin menar vi därför att den postkoloniala traditionen erbjuder viktiga perspektiv som kan användas för att kasta ljus över förorten och den samtida platskampen. Platserna som är hemvist för stadens fördömda, för att tala med Frantz Fanon (1969), blir inte bara en resurs att exploatera utan också ett symboliskt objekt att vulgarisera till syfte att manifestera maktcentrumens moraliska överlägsenhet och dominans. När periferin väl belamras med en mening som symboliserar kaos och fruktan är det således bara kolonialherren som har modet att erbjuda den frälsning och inkluderingens välsignelse.

Forskare verksamma inom en postkolonial tradition har inom en rad olika discipliner visat på hur historiska relationer mellan västerlandet och de "främmande" har gestaltats, hur de har förändrats och hur de har bidragit till att forma samhället till vad det är i dag (Mohanty 2006; Said 1993, 1995). De har inte minst visat hur färgat samhällslivet i stora delar av världen fortfarande är av kolonialismens historia - så även dagens Sverige. "Sverige blev aldrig en kolonialmakt, men den koloniala mentaliteten är i högsta grad närvarande i den svenska idéhistorien" (de los Reyes m.f. 2002, s. I8). Det finns otaliga exempel på hur Sverige inte bara har ingått i och influerats av en bredare kolonial idévärld, utan också aktivt bidragit till densamma - inte minst genom Carl von Linnés systematik över växt-, djur- och människolivet. Enligt en väletablerad svensk självbild har Sverige kommit att stå i frontlinjen för modernitet och upplysning (Ehn m.fl. 1993). Denna självbild har historiskt framträtt i relation till 
"främmande" grupper såväl inom landets gränser - kategoriserade genom benämningar som exempelvis "lappar", "tattare", "zigenare" och "invandrare" (Molina 1997; Vesterberg m.fl. kommande) - som i den omgivande världen (Eriksson Baaz 200ı; Nordvall \& Dahlstedt 2009), där viljan har varit att bidra till upplysning och bildning också i världens avlägsna periferier (Jonsson 2007; Aman 20I4).

För att knyta an till en postkolonial tradition skulle man kunna säga att förortspolitiken i ljuset av statens dominerande drömmar utgör en slags kolonial bumerang (jfr Azar 2006). I samtida berättelser om förorten som ett "parallellsamhälle" ljuder nämligen ett kolonialt eko. Förorten beskrivs som ett område beläget utanför, gestaltat som samhällets mörka utkant, kaotiska områden, med sina egna lagar, regler och normer. En direkt parallell kan dras mellan samtidens fantasier om förortens "parallellsamhälle" och svunna tiders fantasier om djungeln, i världens periferier såväl som i metropolernas utkanter i imperiernas centrum (jfr Ristilammi 1994; Dahlstedt 2005). Det tycks mot bakgrund av denna koloniala fantasi finnas ett ständigt behov hos makthavare att avgränsa förorten från en föreställd svensk normalitet, för att placera diskussionen om samhällets problem, vare sig det rör sig om tillväxt, hållbarhet eller demokrati, till en bekväm plats förlagd utanför samhällets inre dynamik. Problemen tillskrivs därmed "de andra", eftersom de uppvisar så många tecken på att vara i behov av intervention, vilket återkommande motiverar statliga ingrepp och styrning.

I skapandet av förorten som symboliskt objekt kan det överlag tyckas problematiskt att förorten är belägen på svenskt territorium, som del av en svensk samhällsgemenskap. Så varför inte bli av med den en gång för alla? Varför inte riva områden och kvarter och bygga upp en ny tillväxtorienterad, demokratiskt förankrad och hållbar stad från grunden - det har ju skett förr. Men områdena anses inte vara dömda för evigt. Varken militär eller byggföretagens grävmaskiner ska förverkliga en demolering av förorten. Förorten ses inte som bortom räddning, varken från de som bor där eller när det gäller stadens eller statens enträgna strävanden. I dag ser vi en mångfald av ambitioner och interventioner, låt oss kalla dem drömmar, som tillsammans utgör en kamp om platsen eller en platskamp. 


\section{Statliga drömmar}

För att exempelvis kunna förstå hur samtida förslag som att sätta in militär i förorter som ett svar på upptrappat våld och ökad känsla av otrygghet har blivit möjliga, behöver vi se dem i ljuset av de särskilda drömmar och mardrömmar som kommit att bli dominerande. Dessa drömmar och mardrömmar både möjliggör och legitimerar de åtgärder som med olika motiv riktas mot förorten och dess invånare. Något förenklat utgår de ifrån idén om ett konfliktfritt och harmoniskt samhälle, där individens strävanden står i samklang med statens. Eller som etnologen PerMarkku Ristilammi (1994) för mer än två decennier sedan konstaterade: att förorten utgör en slags periferi, som i någon mening är nödvändig för samhällets reproduktion; att genom förorten kan staten framträda som handlingskraftig och initiativtagande, vilket gör det möjligt att återskapa statens politiska makt. Denna makt brukas inte bara för att utnyttja förortens inneboende kraft och resurser, utan också för att tämja dess oberäknelighet.

Den breda repertoar av styrtekniker som utvecklats som ett led i reproduktionen av den sociala ordningen har skett i direkt anslutning till statens närvaro och aktiviteter i den urbana periferin. Dessa tekniker för reproduktion har utgått från en rad offentligt sanktionerade, statsunderstödda drömmar. Genom exempelvis antisegregationsåtgärder har flera omgångar av förortspolitikens tidsbundna, områdesavgränsade, samverkansorienterade och selektiva projekt omvandlat förorterna till ett slags experimentverkstäder för olika sociala projekt (jfr Kings 20Ir; Dahlstedt 20I8; Urban 20I8). Segregationen och de ojämlika villkoren har dock inte bara bestått, utan ytterligare intensifierats. Redan för tio år sedan konstaterade Roger Andersson (2008, s. 155): "politikerna fortsätter att se segregationen som ett problem för vissa (utsatta) stadsdelar, inte för hela staden". Dessutom har allt fler stadsdelar runt om i landet kategoriserats som "problemområden" eller "särskilt utsatta" under antisegregationspolitikens etablerande som permanent och projektbaserad politik. De första interventionerna inriktades mot tiotalet stadsdelar, medan de nu rådande statliga definitionerna inriktar sig mot alltifrån ett trettio- till ett sextiotal grannskap (Dahlstedt 20I8). 
Det som kännetecknar det symboliska objektets fixering och till synes gränslösa spridning är att allehanda samhällsproblem reduceras till den banala förekomsten av "problemområden"; inte minst tydligt under valåret 20I8. Segregationen och utanförskapet ses huvudsakligen som problem förlagda i stadens utkanter. Problemet, såsom det urskiljs, kräver särskilda, områdesbaserade åtgärder. Även om det redan tidigare har konstaterats att områdesbaserade åtgärder inte löser segregationens problem, att de kanske snarare möjliggör och utgör en grund för fortsatta åtgärder av liknande slag, så vill vi här se dessa interventioner som uttryck för särskilda statliga strävanden. Låt oss kalla dem statliga drömmar. Vilka är då dessa drömmar? Vad är det för insatser de möjliggör? I olika perioder har olika begrepp och styrningstekniker stått i förgrunden för interventioner. Statens strävanden av i dag kan bland annat ringas in genom drömmen om hållbarhet och tillit.

Som ett svar på tillväxtens sociala, ekonomiska och ekologiska tillkortakommanden har frågan om social hållbarhet på senare tid fått en status som samlande kraft och vilja inför framtiden. I drömmen om social hållbarhet finns ett löfte om skapande eller snarare återskapande av sammanhållning, i en värld full av hot och konflikter. Även om den allmänna uppmaningen i denna dröm är att samhället i stort behöver ställa om till hållbarhet, så är det först och främst vissa bestämda platser och deras individer som uppmaningen riktas särskilt starkt mot - däribland förorten (Boverket 20IO). På en rad olika sätt ses nämligen förorten som en i någon mening ohållbar plats, en plats vid sidan av. Byggnaderna i förorten faller samman och kräver stora resurser för att renoveras så att de håller fullgod standard. Invånarna är beroende av dyra vårdinsatser och omsorg och står därtill utanför den "närande" sektorn, "beroende" av bidrag och inte tillräckligt anställningsbara. Invånarna beskrivs som avskurna och isolerade från världen utanför förorten, geografiskt såväl som socioekonomiskt och sociokulturellt (se t.ex. Formas 20I2). Sammantaget återkommer här en bild av förorten som stadens baksida, ett resursmässigt slukhål som dränerar samhället och stadens framsida på ekologiska, ekonomiska och sociala värden.

Paradoxen är att förortens resurssvaga befolkning står för en relativt mindre andel av landets konsumtion av klimatskadliga resurser och 
bostadsområdena är på flera sätt planerade för livsstilar där kommersiell konsumtion inte står i fokus. Utan den resurs i form av arbetskraft och arbetskraftsreserv som förortens befolkning utgör för entreprenörsstadens ökade behov av lågkvalificerade servicetjänster blir stadens ekonomi dessutom förlamad. I stället för att adressera de problem som denna befolkning själva upplever i sin vardag, fungerar den sociala hållbarhetens målsättningar snarare som fantasifulla dekorativa element i policyplaner med syftet att åstadkomma en känslomässig gemenskap och attraktion till entreprenörsstadens politiska agenda (Gressgård 20I5; Tahvilzadeh m.fl. 20I7). För förorten förvandlas hållbarhetsprojekten inte sällan till omfattande renoveringar som bidrar till ökade och oskäliga levnadskostnader för de boende. Eller så reduceras projekten till "välvilliga" satsningar på sociala projekt såsom lokala arbetsförmedlingar, läxhjälp eller mötesplatser. Sammantaget reduceras stadens ohållbara sammanhållning i ljuset av skenande polarisering till en fråga om förortsbornas (o)medgörlighet när det gäller att finna sig i den sociala ordningens hierarkier.

Drömmen om tillit kan ses som en dröm om harmoni, där strävan efter tillväxt måste förankras demokratiskt genom att stadsinvånarnas förtroende, gemenskap och sociala band stärks för att kunna vara hållbar. Det är därför inte överraskande att det i detta sammanhang ofta anses vara förortsbornas brist på just tillit till och känsla av samhörighet med samhället, såsom det manifesteras av dess nyckelinstitutioner, som är det verkligt stora hotet mot den fortsatta färden mot en hållbar framtidsdröm.

Förortsborna röstar i betydligt mindre utsträckning, uppvisar avsevärt lägre tilltro till myndigheter och deltar oftare i ideella organisationer som anses alltför slutna, jämfört med invånarna $\mathrm{i}$ andra delar av städerna (Kings 20II). Enligt denna beskrivning utgör förorten följaktligen en slags politikens skuggsida (Strömblad 2003). Insatser för att öka invånarnas deltagande kan vi se i form av en snabbt ökande repertoar av olika delaktighetsforum som medborgarråd, dialoger, partnerskap och demokratievenemang. Det visar sig ha mindre betydelse att en rad studier gång på gång har påvisat demokratiexperimentens symboliska karaktär och begränsade förmåga att åstadkomma större förändringar när det gäller 
hur beslut fattas och prioriteringar görs (Tahvilzadeh 2015; Kugelberg \& Trovalla 20I5). Det är likväl förortens koppling till (icke)deltagande och "extremism" som gång på gång problematiseras, snarare än den existerande demokratins sätt att fungera.

I de många samtida interventionerna i förorter blir de statliga drömmarna till verklighet. I detta nummer görs tre distinkta nedslag på det här temat. En central institution för reproduktionen av den sociala ordningen är skolan som i sig präglas av en rad pågående förändringsprocesser och interventioner. I "Förändringens agenter. Om skola, prevention och fostran till trygghet" diskuterar Magnus Dahlstedt och Christophe Foultiers så kallade trygghetsskapande åtgärder i skolan. Utgångspunkten är en specifik lokal intervention som bygger på brottsförebyggande fostran. I artikeln analyseras denna fostran som uttryck för en vilja att aktivera, som manar till individens motivation och vilja att göra aktiva val och ställningstaganden - i namn av frihet, ansvarstagande och trygghet. I denna fostran är det huvudsakligen individens anpassning till den rådande sociala ordningen som är ledmotivet, snarare än förändring av rådande sociala villkor. Trygghetstemat diskuteras vidare av Vanja Lozic som undersöker nya recept för det lokala brottspreventiva arbetet som centreras kring det omhuldade begreppet "samverkan". I fokus för artikeln "Att lära av det lokala och experimentera. Resilienstänkande i brottsförebyggande arbete" står ett specifikt samverkansprojekt för att skapa säkerhet och trygghet i ett marginaliserat bostadsområde i fokus. Studien visar att överskridande av professionella och organisatoriska gränser har inneburit en förskjutning av maktrelationer och styrning: från en tydlig ansvarsfördelning och centralt fastställda organisationsramar till ett mer informellt och nätverksbaserat beslutsfattande, reflexiv styrning, affektiva arbetssätt och förskjutning av ansvaret till individer. I ett vidare perspektiv visar båda dessa bidrag att återigen är det i allt väsentligt stadens periferier som utmålas som problem och som i behov av intervention. Samtidigt som det finns en idé om att lösningarna ska komma från området självt, så behöver förändringsprocessen initieras utifrån, definierad med utgångspunkt i de viljor, premisser och intressen som finns där. I det tredje nedslaget med titeln "Att göra kaos. Om förortspolitiken som urban styrregim och demokratiskt spel” av Nazem 
Tahvilzadeh och Lisa Kings synliggörs just gränserna för vad förorten får drömma om inom ramen för förortspolitiska interventioner. Utgångspunkten är den omfattande kritik som organisationen Megafonen möttes av efter att ha hoppat av ett kommunalt stadsutvecklingsprojekt. Den starka reaktion och omilda behandling som mötte de unga aktivisterna förstås här i relation till förortspolitikens lokala interventioner. Tahvilzadeh och Kings menar att de otaliga områdesavgränsade projekten har skapat en särskild politisk ordning som premierar samförstånd mellan stat och civilsamhälle, vilket skapar begränsade förutsättningar för kritiska röster i den urbana periferin. Detta förklarar i sin tur det motstånd Megafonen mötte när de gjorde "kaos", det vill säga valde att ställa sig utanför de konsensusinriktade projekten.

\section{Förortens drömmar}

De statliga drömmarna står emellertid inte oemotsagda. För oavsett vad staten drömmer om och hur dessa drömmar iscensätts så möter de förr eller senare individer och grupper i förorter, med olika erfarenheter, förutsättningar och viljor. Förortens drömmar, eller kanske snarare drömmar från förorten, får dock vanligtvis mindre uppmärksamhet. På samma sätt som det finns en uppsjö av olika medel för att intervenera i förorten finns det en bred spännvidd av olika sätt som förortens invånare förhåller sig till statens interventioner. Dessa förhållningssätt är såväl individuellt som kollektivt orienterade, i ett spektrum som rör sig mellan å ena sidan individuell resignation och internaliserat självförakt och å andra sidan organiserat kollektivt motstånd. Inget är givet på förhand, utan den dynamik som uppstår mellan å ena sidan statsapparatens funktioner och interventioner och å andra sidan förortens invånare, deras viljor och agens, är något som närmare behöver analyseras, utifrån sin specifika kontext.

Den samtida staden är, förutom att vara en strategisk plats för kommodifieringsprocesser, också ett säte för motstånd och alternativa visioner (jfr Castells 1983; Thörn 20I3; Nicholls \& Uitermark 2017). I linje med den övergripande ambitionen med detta specialnummer ser vi ett särskilt behov av att lyfta fram motsättningar, att synliggöra politiska 
strategier och livssammanhang i den urbana periferin. Genom att synliggöra drömmar från förorten uppmärksammas vikten av aktörskap hos dem som anses behöva särskild styrning för att leva upp till statens drömmar. Med denna ansats vill vi bidra till att å ena sidan tydliggöra hur ojämlikhetsprocesser både motarbetas och reproduceras. Vi vill å andra sidan återknyta detta till den styrande ansatsen i statens drömmar, då ett aktörsperspektiv också kan bidra med att synliggöra nya aspekter eller nyanser av ojämlikhetsprocesser (Leitner m.fl. 2007).

Vissa drömmar från förorten, särskilt tonsatta sådana, har emellertid fătt större genomslag i den publika diskussionen än andra. Hiphop och hiphop-rörelsen i Sverige har länge haft en dominerande position som förortens uttolkare. Hiphop har i vetenskapliga studier liknats vid gränsöverskridande gemenskaper och samtidigt som rörelsen innehåller element av en "försvarskultur" innehåller den även politiserande inslag som till exempel offensivt kommenterar den samtida rasismen (Sernhede 2002; Dahlstedt 2005; Dahlstedt \& Ålund 2018). I detta nummer får emellertid populärkulturen stå tillbaka för andra typer av röster, eller i alla fall andra sätt att uttrycka sin röst på.

Framväxten av en stadsöverskridande förortsrörelse som under några år blev en viktig aktör i den samhälleliga debatten om ojämlikhet och rasism i relation till platsfrågor knyter samman flera av numrets bidrag. En av dessa är René León Rosales och Aleksandra Ålunds artikel "Aktivism som platskamp. Självpositionering och medborgarskapande inom den svenska förortsrörelsen”. Här undersöker de hur identitetsskapande processer kan kopplas till motstånd mot en ojämlik samhällsordning. Förortsrörelsens platskamp för att förändra den egna rumsliga verkligheten och de maktförhållanden som orsakar förortens utsatthet speglas här i livsberättelsen om en ung kvinna, som var aktiv i en av rörelsens organisationer under flera år. Genom livsberättelsen och belägenheten som ung, kvinna och förortsbo framhåller de att situerad kunskap är både en orsak till och en förutsättning för aktivism. Förortsrörelsens platskamp möjliggörs på så sätt genom relationen mellan individuell erfarenhet och kollektiv handling. Både León Rosales och Ålund och den tidigare nämnda artikeln av Tahvilzadeh och Kings tar på olika sätt avstamp i organisationen Megafonens tillblivelse och utveckling för att skapa för- 
ståelse för hur förorten kan forma egna drömmar i stormens öga. Men varifrån vinden i stormens öga blåser kan växla snabbt. Under kort tid gick de unga aktivisterna från att omhuldas som förortens framtid till att bli hårt ansatta av observatörer och tidigare samverkanspartner. Men organisationen erövrade också tidigt sympatier och mobiliserade stöd från en rad individer i betydelsefulla organisationer som bestod under stormarna. I artikeln "Betydelsen av brobyggare. Det etablerade civilsamhället och förortsrörelsen” studerar Lisa Kings så kallade brobyggare, det vill säga tjänstepersoner inom det etablerade civilsamhället som har fungerat som en länk mellan traditionella civilsamhällesorganisationer och den nya rörelsen och tvärtom. Mellan förortsrörelsens aktivister och brobyggarna utvecklades ett nätverk och en lärprocess. Brobyggarna använde bland annat sin roll och position för att stödja den urbana rättviserörelsens uppstart, men av särskild vikt var framför allt att förortsrörelsens grundläggande idéer och legitimering har varit viktiga för brobyggarna i arbetet med att försöka vitalisera deras egna etablerade civilsamhällesorganisationer. Detta leder till en mer övergripande diskussion om en ökad distans inom olika delar av civilsamhället av i dag och den framtida betydelsen av så kallade brobyggare.

Men förortsborna själva drömmer också om annat än det som ryms inom kollektiv organisering för samhällsförändring. I Magnus Dahlstedt och James Frempongs bidrag "Stå upp för orten. Ungdomar, utanförskap och förortsdrömmar" framstår möjligheten till individuell förändring som mycket mer angelägen än den kollektiva kampen för en annan drömmars stad. De riktar fokus mot ungdomar i ett förortsområde och hur deras berättelser om tillvaron både här och nu och om framtiden formas i relation till omgivningens dominerande berättelser om förorten. När det gäller ungdomarnas berättelser om framtiden så är det individuella scenarier riktade mot förorten som står i förgrunden, medan scenarier som bygger på kollektiv handling riktade mot världen utanför lyser med sin frånvaro. För att förändring ska bli möjlig är det upp till förortens ungdomar att ta eget ansvar och att stå upp för sig själva. 


\section{Mot nya drömmar}

Artiklarna i detta specialnummer ger med olika fördjupningar inblick i den samtida kampen om förorten, i skärningspunkten mellan statens och ortens egna drömmar. De exempel som tas upp är inte heltäckande, men frilägger likväl sprickor som följer av samtidens paradoxala politiska landskap. Många är tillbuden om att förortens befolkning ska anpassa sig till och acceptera den rådande ordningen, samtidigt som gränserna för vad en acceptabel medborgare eller plats i staden egentligen är hela tiden förflyttas. I denna ständigt omförhandlade gräns mellan vilka som anses "innanför" och "utanför" blir förorten till. Vår förhoppning är att detta nummer ska bidra till diskussionen om förorten och den polariserade staden på ett sätt som gör att vi kan röra oss bort från viljan att göra ett bokslut över vad "förorten" är. I stället vill vi närma oss en kritisk analys som riktas mot de mekanismer som gör förorten till det som den har kommit att bli, för att på så sätt kunna tänka annorlunda - vad förorten skulle kunna vara.

Det finns inte en förort, ett sätt att ge mening åt förorten, utan en mångfald av förorter och sätt att ge mening åt förorten. Förorten kan här med andra ord ses som ett fönster som gör det möjligt att iaktta och förstå en mer allmän utveckling. För att kunna utmana de drömmar och åtgärder som kommit att bli dominerande så är det viktigt att synliggöra de sprickor som präglar den samtida politiska kampen om förorten. Bidragen i detta temanummer skaver mot varandra. Just därför fångar de samtidigt platskampernas friktioner, vilket förhoppningsvis öppnar upp för nya samtal om detta ständigt återkommande tema: förorten, levd som föreställd. 


\section{Referenser}

Aldén, Lina, Hammarstedt, Mats \& Neuman, Emma (2015) "Ethnic segregation, tipping behavior, and native residential mobility", International Migration Review, 49, I, s. 36-69. DOI: https://doi.org/IO.IIII/imre.I2066

Aman, Robert (2014) Impossible interculturality? Education and the colonial difference in a multicultural world. Institutionen för beteendevetenskap och lärande, Linköpings universitet.

Andersson, Roger (2008) "Skapandet av svenskglesa områden", i Magnusson Turner, Lena (red.) Den delade staden. Segregation och etnicitet i stadsbygden. Umeå: Boréa.

Andersson, Roger, Bråmå, Åsa \& Hogdal, Jon (2009) Fattiga och rika - segregerad stad. Flyttningar och segregationens dynamik i Göteborg 1990-2006. Göteborg: Göteborgs stad.

Azar, Michael (2006) Den koloniala bumerangen. Från schibbolet till körkort i svenskhet. Eslöv: Symposion.

Boverket (2010) Socialt hållbar stadsutveckling-en kunskapsöversikt, rapport från Boverket. URL: https://www.boverket.se/globalassets/publikationer/dokument/20Io/socialthallbar-stadsutveckling.pdf (28 mars 20I8)

Brenner, Neil \& Theodore, Nikolas (2002) "Cities and the geographies of 'actually existing neoliberalism"', i Brenner, Neil \& Theodore, Nikolas. (red.) Spaces of neoliberalism. Urban restructuring in North America and Western Europe. Malden: Blackwell.

Castells, Manuel (1977) The urban question. A Marxist approach. London: Arnold.

Castells, Manuel (1983) The city and the grassroots. A cross-cultural theory of urban social movements. Berkeley: University of California Press.

Cockburn, Cynthia (1977) The local state. Management of cities and people. London: Pluto Press.

Dahlstedt, Magnus (2005) Reserverad demokrati. Representation i ett mångetniskt Sverige. Umeå: Boréa.

Dahlstedt, Magnus (2016) "Drömmarnas och mardrömmarnas stad", i Tesfahuney, Mekonnen \& Ek, Richard (red.) Den postpolitiska staden. Sandared: Recito.

Dahlstedt, Magnus (red.) (2018) Förortsdrömmar. Ungdomar, utanförskap och viljan till inkludering. Linköping: Linköping University Electronic Press.

Dahlstedt, Magnus \& Ålund, Aleksandra (2018) "Den nya svenska förortsrörelsen - viljan att höra hemma", i Dahlstedt, Magnus (red.) Förortsdrömmar. Ungdomar, utanforskap och viljan till inkludering. Linköping: Linköping University Electronic Press. de los Reyes, Paulina, Molina, Irene \& Mulinari, Diana (2002) "Introduktion", i de los Reyes, Paulina, Molina, Irene \& Mulinari, Diana (red.) Maktens (o)lika förklädnader. Kön, klass \& etnicitet i det postkoloniala Sverige. En festskrift till Wuokko Knocke. Stockholm: Atlas.

Ehn, Billy, Frykman, Jonas \& Löfgren, Orvar (1993) Försvenskningen av Sverige. Det nationellas forvandlingar. Stockholm: Natur \& Kultur.

Ericsson, Urban (2007) Belägrade människor - belägrade rum. Om invandrargöranden och förorter. Institutionen för kulturantropologi och etnologi, Uppsala universitet. 
Eriksson Baaz, Maria (200I) "Biståndet och partnerskapets problematik", i Mc Eachrane, Michael \& Faye, Louis (red.) Sverige och de Andra. Postkoloniala perspektiv. Stockholm: Natur \& Kultur.

Fanon, Frantz (1969) Jordens fördömda. Stockholm: Rabén \& Sjögren.

Fell, Terence \& Guziana, Rozena (2016) Stad, rättvisa och boendesegregering. Stadsområdesutveckling i Eskilstuna och Västerås 2002-20I2. Västerås: Mälardalens högskola.

Formas (2012) Miljonprogrammet - utveckla eller avveckla?, rapport från forskningsrådet Formas.

URL: http://www.formas.se/PageFiles/3678/miljonprogrammet_utveckla_eller_ avveckla.pdf (28 mars 20I8)

Franzén, Mats, Hertting, Nils \& Thörn, Catharina (2016) Stad till salu. Entreprenörsurbanismen och det offentliga rummets värde. Göteborg: Daidalos.

Gressgård, Randi (2015) "The power of (re)attachment in urban strategy. Interrogating the framing of social sustainability in Malmo", Environment and Planning A: Economy and Space, 47, I, s. I08-120.

DoI: https://doi.org/Io.Io68/ai30i67p

Harvey, David (1976) "Labor, capital, and class struggle around the built environment in advanced capitalist societies", Politics \& Society, 6, 3, s. 265-295. DoI: https://doi.org/IO.II77/00323292760060030I

Harvey, David (1989) "From managerialism to entrepreneurialism. The transformation in urban governance in late capitalism", Geografiska Annaler, 7I, I, s. 3-I7. DOI: https://doi.org/I0.2307/490503

Holgersen, Ståle (20I7) Staden och kapitalet. Malmö och krisernas tid. Göteborg: Diadalos.

Jonsson, Stefan (2007) "Apans bildningsresa”, i Gustavsson, Bernt (red.) Bildningens förvandlingar. Göteborg: Daidalos.

Kings, Lisa (20II) Till det lokalas försvar. Civilsambället $i$ den urbana periferin. Lund: Arkiv.

Kugelberg, Clarissa \& Trovalla, Eric (2015) Samverka ochleller styra. Att praktisera medborgarinflytande i planering och beslutsfattande. Göteborg: Makadam.

Leitner, Helga, Peck, Jamie \& Sheppard, Eric S. (red.) (2007) Contesting neoliberalism. Urban frontiers. New York: Guilford Press.

Lilja, Elisabeth (20II) Den segregerade staden. Tre kvarter i Stockholms innerstad. Stockholm: Stockholmia.

Magnusson Turner, Lena (red.) (2008) Den delade staden. Segregation och etnicitet i stadsbygden. Umeå: Boréa.

Massey, Doreen B. (2005) For space. London: Sage Publications.

Mohanty, Chandra Talpade (2006) Feminism utan gränser. Avkoloniserad teori, praktiserad solidaritet. Stockholm: Tankekraft.

Molina, Irene (1997) Stadens rasifiering. Etnisk boendesegregation i folkhemmet. Uppsala: Uppsala universitet.

Nicholls, Walter J. \& Uitermark, Justus (2017) Cities and social movements. Immigrant rights activism in the US, France, and the Netherlands, 1970-20I5. Chichester: Wiley Blackwell. 
Nordvall, Henrik \& Dahlstedt, Magnus (2009) "Folkbildning i (av)koloniseringens skugga. Demokrati, nationella mytologier och solidaritetens paradoxer", Utbildning \& Demokrati, 18, 3, s. 29-48.

Pripp, Oscar (2002) "Mediabilder och levd erfarenhet", i Ramberg, Ingrid \& Pripp, Oscar (red.) Fittja, världen och vardagen. Tumba: Mångkulturellt centrum.

Ristilammi, Per-Markku (1994) Rosengård och den svarta poesin. En studie i modern annorlundahet. Stehag: Symposion.

Said, Edward W. (1993) Orientalism. Stockholm: Ordfront.

Said, Edward W. (I995) Kultur och imperialism. Stockholm: Ordfront.

Salonen, Tapio (red.) (20II) Hela staden. Social hållbarhet eller desintegration. Umeå: Boréa.

SCB (20I4) Segregation i Stockholm län. Demografisk rapport 20I4:09, rapport från Statistiska centralbyrån.

URL: http://www.rufs.se/globalassets/h.-publikationer/20I4_09.pdf (28 mars 2018)

Sernhede, Ove (2002) Alienation is my nation. Hiphop och unga mäns utanförskap i det nya Sverige. Stockholm: Ordfront.

Socialstyrelsen (20I0) Social rapport 20I0. Stockholm: Socialstyrelsen.

Stigendal, Mikael (2016) Samhällsgränser. Ojämlikhetens orsaker och framtidsmöjligheterna $i$ en storstad som Malmö. Stockholm: Liber.

Strömblad, Per (2003) Politik på stadens skuggsida. Uppsala: Acta Universitatis Upsaliensis.

Tahvilzadeh, Nazem (2015) "Det våras för medborgardialoger", i Làt fler forma framtiden! Forskarantologi. Bilaga till betänkande av 2014 års Demokratiutredning - Delaktighet och jämlikt inflytande, SOU 2015:96. Stockholm: Fritzes.

Tahvilzadeh, Nazem, Montin, Stig \& Cullberg, Mikael (2017) "Functions of sustainability. Exploring what urban sustainability policy discourse 'does' in the Gothenburg metropolitan area", Local Environment, 22, suppl. I, s. 66-85.

DoI: https://doi.org/Io.IO80/I3549839.2017.1320538

Tedros, Adiam (2008) Utanför storstaden. Konkurrerande framställningar av förorten $i$ svensk storstadspolitik. Förvaltningshögskolan, Göteborgs universitet.

Thörn, Håkan (2013) Stad i rörelse. Stadsomvandlingen och striderna om Haga och Christiania. Stockholm: Atlas akademi.

Urban, Susanne (20I8) Integration och grannskap. Hur kan staden hålla samman? Lund: Studentlitteratur.

Vesterberg, Viktor, Dahlstedt, Magnus \& Härnbro, Simon (kommande) ”De resande och den hotfulla rörligheten”, i Dahlstedt, Magnus (red.) Gränsöverskridande socialt arbete. Malmö: Gleerups.

Wallerstein, Immanuel (2007) Världssystemanalysen. En introduktion. Stockholm: Tankekraft. 


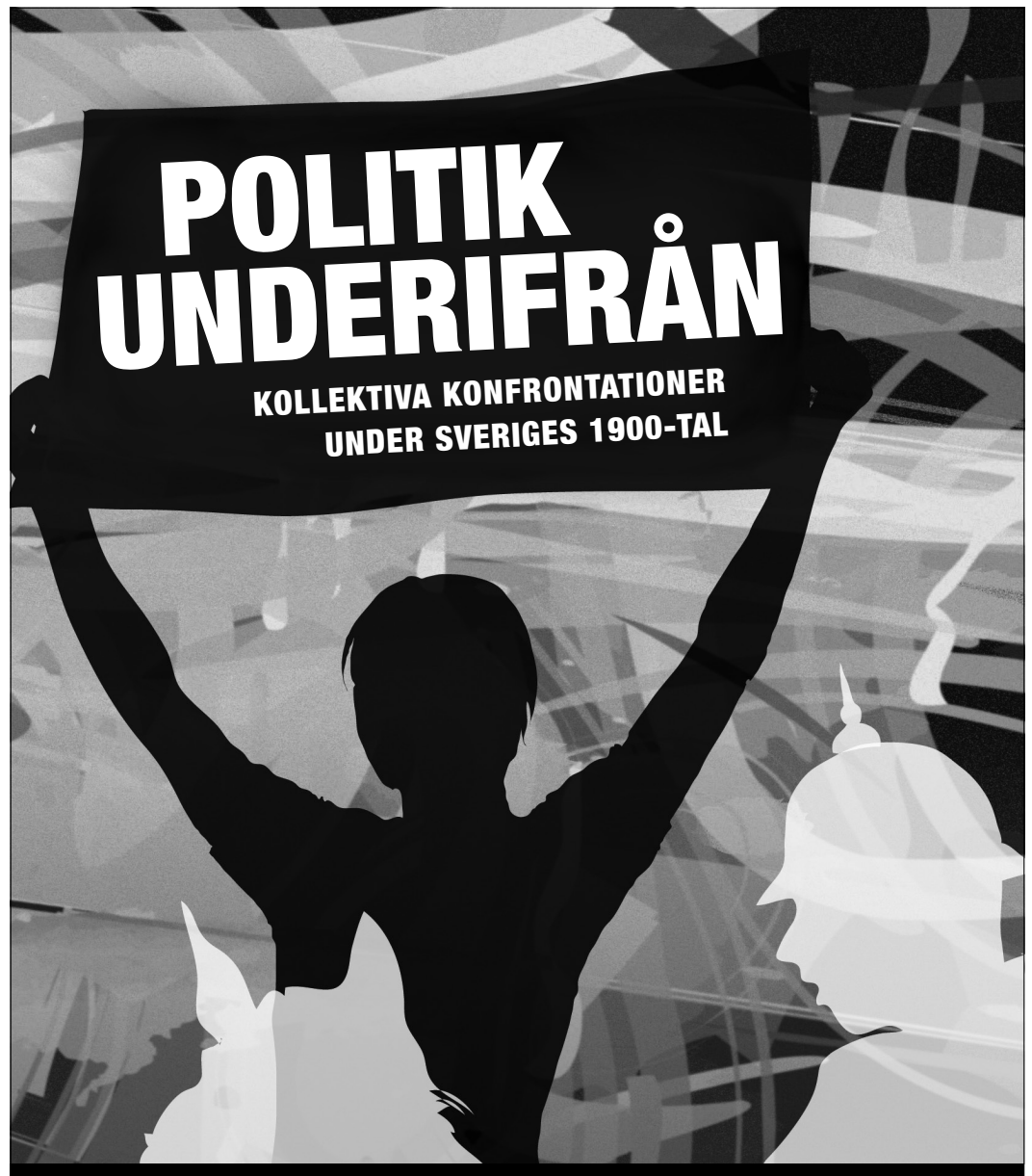

I POLIIK UWDERIFRÅN skriver historiker och samhällsvetare om politiska och sociala konflikter i 1900-talets Sverige då människor har brutit mot den dominerande politiska kulturens normer för hur man får göra politik och vilka som får delta i politiska processer. Från rösträttsstriden i början av seklet, över gatukravaller, vilda strejker och den gryende miljörörelsens kamp, till konflikter om vem som har rätt att använda det urbana rummet åren efter murens fall.

Andrés Brink Pinto \& Martin Ericsson (red.), Arkiv förlag, 216 sidor

\section{"LÄS MER OM BOKEN PÅ WWW-ARKIWNUW}

